DOI: https://doi.org/10.34069/AI/2021.45.09.1

How to Cite:

Ivaniuk, H., Oleksiuk, O., \& Vyshnevetska, M. (2021). Sociocultural dominants of developing students' value intentions: context of civilization challenges. Amazonia Investiga, 10(45), 9-19. https://doi.org/10.34069/AI/2021.45.09.1

\title{
Sociocultural dominants of developing students' value intentions: context of civilization challenges
}

\section{Соціокультурні домінанти розвитку ціннісних інтенцій студентів: контекст цивілізаційних викликів}

Received: August 2, 2021

Accepted: September 25, 2021
Written by:

Hanna Ivaniuk ${ }^{1}$

https://orcid.org/0000-0001-7758-5121

Olha Oleksiuk ${ }^{2}$

https://orcid.org/0000-0002-7785-1239

Maryna Vyshnevetska

https://orcid.org/0000-0001-5830-6406

\begin{abstract}
The study of the influence of sociocultural dominants on value intentions formation in young generation of specialists (teachers) is important for identifying useful ideas that can be implemented to improve axiological situation in the country and the world in accordance with civilization challenges. The article highlights a wide range of theoretical achievements and presents results of empirical research, which confirms positive dynamics of value intentions development in students of pedagogical and art specialties. Generalized conclusions about development of this important phenomenon in the context of declining demand for value dominants, are confirmed by statistics. The study was based on axiological, socio-cultural, systemic and interdisciplinary research. The research field consisted of educational institutions in Kyiv (Ukraine), the sample was 356 respondents (students of the first bachelor's level). The adequacy of the applied experimental tools (questionnaires, Pedagogical essays) is proved. The experimental work was conducted online using Google services. The results of the study show positive dynamics of the value intentions development and a significant correlation between students' motivation to value-oriented activities and sustainability of this direction in the future. The importance of sociocultural determinants in the development of value intentions in students of pedagogical
\end{abstract}

\begin{abstract}
Анотація
Дослідження впливу соціокультурних домінант на формування ціннісних інтенцій молодої генерації фахівців (педагогів) $\epsilon$ важливим для виявлення корисних ідей, що можуть упроваджуватися для покращення аксіологічної ситуації в країні та світі відповідно до цивілізаційних викликів. У статті висвітлено широкий пласт теоретичних здобутків та подано результати емпіричного дослідження, що підтверджують позитивну динаміку розвитку ціннісних інтенцій у студентів педагогічних i мистецьких спеціальностей. Узагальнені висновки щодо розвитку цього важливого феномену в умовах зниження запитів на ціннісні домінанти, підтверджено статистичними даними. Дослідження грунтується на аксіологічному, соціокультурному, системнодіяльнісному i міждисциплінарному дослідженні. Дослідницьке поле становили заклади освіти міста Києва (Україна), вибірка становила 356 респондентів (студенти першого бакалаврського рівня). Доведено адекватність застосованих експериментальних інструментів (анкети, опитувальні аркуші, педагогічні есе). Експериментальна робота проводилась в онлайн режимі 3 використанням Гугл-сервісів. Результати вивчення показують позитивну динаміку розвитку ціннісних інтенцій та значну кореляцію між мотивацією студентів до
\end{abstract}

\footnotetext{
${ }^{1}$ Doctor of Pedagogical Sciences, Professor, Head of the Chair of Pedagogy and Psychology, Borys Grinchenko Kyiv University, Kyiv, Ukraine.

${ }^{2}$ Doctor of Pedagogical Sciences, Professor, Head of the Chair of Musicology and Music Education, Borys Grinchenko Kyiv University, Kyiv, Ukraine.

${ }^{3} \mathrm{PhD}$ Student, Borys Grinchenko Kyiv University, Kyiv, Ukraine.
} 
specialties based on sociocultural knowledge is proved.

Keywords: sociocultural dominants, values, value intentions, students of pedagogical specialties, interdisciplinary research. цінніснозначущої діяльності і сталість цієї спрямованості у майбутньому. Вперше за результатами наукового пошуку маємо змогу зробити доконаний висновок про важливість соціокультурних детермінант у розвитку ціннісних інтенцій студентів педагогічних спеціальностей, що грунтуються на гуманітарних соціокультурних знаннях.

Ключові слова: соціокультурні домінанти, цінності, ціннісні інтенції, студенти педагогічних міждисциплінарні дослідження. спеціальностей,

\section{Introduction}

Formation of the cultural space of a person, a specialist involves synthesis of general scientific knowledge with the culture of the era (human civilization). In this context, we consider of primary importance the interpenetration of professional knowledge and human values, knowledge of the nature and technology and knowledge of man and sense of his existence. Since modern civilization is largely technocratic, the purpose of education in general and art education in particular is to assimilate the values of the social environment culture. Sociocultural dominants constitute the basis of the value intentions of future teachers - specialists in musical art because they represent the following personal components: volitional (desire to perceive, act, create); desire (intention) for value self-improvement; emotional (evaluative). Students of pedagogical and artistic specialties are a special age group which is characterized by a desire for dominant values: search for truth, charity in sociocultural centers, openness to aesthetics and spiritual practices. Therefore, in the educational process of universities it is important to cultivate values that are important for the social practices of future professionals and focused on the development of personal axiological intentions, and thus determine the vector of selfdevelopment of the student's personality.

Note that sociocultural dominants are highlighted in the context of modern basic concepts of culture, as a set and enrichment of cultures in the space of human life. In the conditions of digital civilization and rapid globalization, the problem of preserving deep values, which are equally important for people of different cultures, becomes relevant. In the process of teacher training, we focus on the fact that a future specialist will work with children who will bring motives, needs and assessments that differ greatly from those established in previous generations.
The aim of the article is to reveal the generalized results of scientific research on the formation of university students' readiness to choose sociocultural dominants for the development of their value intentions on humanistic ideas that determine their self-affirmation and selfdevelopment.

The results of theoretical analysis have revealed various approaches of scientists to the study of the sociocultural component in the development of value orientations of student youth, which allowed to substantiate the concepts of "sociocultural dominants", "value intentions" and their impact on professional development. The conducted interdisciplinary research confirms relevance of this direction due to the needs of modern human civilization. The highlighted results of empirical research in the context of the article made it possible to generalize the scientific and practical significance of students' value intentions development based on sociocultural dominants and contributed to their self-improvement in personal and professional senses in civilizational shifts.

\section{Literature Review}

Modern researchers argue that in the interdisciplinary dimension a prominent place occupy sociocultural dominants in the process of assimilation by the young generation of such eternal values as wisdom, truth, justice, freedom and equality, ethics, kindness and justice (Elior, 2011). We support the above considerations, given that they are characterized by longevity, rooted in the traditional sociocultural and modern cultural background.

In line with the problems of the article, valuable is interdisciplinary research in the field of social sciences (pedagogy, psychology) and arts, based on the classical understanding, according to 


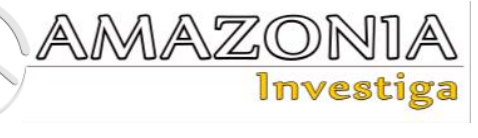

which the vision of humanities is to form thinking open to everything new and respect for past as well as to create the society that supports value dominants of culture and ethics development. The study of various aspects of the influence of sociocultural dominants on value intentions development in future teachers ensures preservation of cultural ties between generations. This idea was substantiated by the ancient Greek philosopher Plato, who considered the sciences of man to be related to the humanities and serve as a means of conscious comprehension of the meaning of life (Goldman, 2014).

A retrospective review of scientific sources has revealed that in the sociocultural dimension (from the historical period of Hellenic culture to today's European culture) it was the sciences of man and his values that expressed the humancreating mission of civilization. In contrast to the current popularization of the technological education strategies, Western European history of education in previous periods (XIX-XX centuries) contains productive models built on the priority of studying the humanities, which were considered the key to human selfimprovement. The sciences of man and his values were a tool for achieving his goals and personal success. The study of different models of education in Western Europe suggests that the priority strategy is axiological, and therefore interdisciplinary research occupies a prominent place in human adaptation in a changing world (Rinon, 2014).

In the modern intercultural space, the issue of personal values and, above all, values of future professionals, has been studied multifacetedly. In particular, interesting are the studies presented in the monographs "Horizon of education spirituality" and "Ugdymo dvasingumas" on the spiritualization of the educational environment on the basis of anthropocentrism. The spirituality of the individual is considered by modern scholars in connection with culture. This approach makes it possible to highlight sociocultural dominants against the background of a wide cultural field (Kevishas \& Otych, 2019). In line with the issues of the article, a prominent place belongs to research on the development of spiritual potential of the individual in post-classical art education on the basis of anthropological and interdisciplinary approaches - O Oleksiuk (Oleksiuk, 2019), J. Uchyła-Zroski (Uchyła-Zroski, 2016); value competences and their essence are revealed in the work of I. Bekh (Bekh, 2019).
The issue of values is multifaceted. In the research of modern scientists, a significant place is given to the study of the values of professional and pedagogical activities, including the value attitude and motivation to the teaching career. Of scientific importance is the study of various aspects of the students' humanistic orientation development by different types of values, general orientation and self-esteem (Orekhova et al., 2020); theoretical foundations and models of values development in higher education applicants of the specialty "Primary Education" (Panev, 2020); value regulation of the education managers' activities (Zhussupova et al., 2020). For our study, of particular interest is the impact of value orientation on the efficiency of the generation $\mathrm{Z}$ in the educational process, including gender dimension (Starecek et al., 2019). Important for the work are comparative approaches to the study of the similar problem, including foreign experience, - values of higher education applicants (González-Gijón et al., 2020).

In a number of works of modern scientists some aspects of the problems mentioned in the article are covered. Thus, the article "Formation of students' values-based attitude to the future teaching profession as moral basis of pedagogical ethics" highlights the values of future teachers in line with modern social realities and culture of society (Orekhova et al., 2020).

Some ideas of the above article correspond to the conclusions of the present article. In line with its issues, the article "Value-centric education: A transcending approach" is of interest. Its author pays attention to revealing the essence of valuecentric learning in the context of a new educational philosophy that integrates modern experience and traditions (Lyberger, 2020).

The relevance of values development in current generation is revealed in the article "Value orientations of generation $\mathrm{Z}$ and their performance in education process", which highlights the impact of value orientations on generation $\mathrm{Z}$ in the educational process and substantiates research tools that have revealed the relationship between the cognitive level and moral-value orientation of the personality (Starecek et al, 2019).

Of considerable interest is the article "Study of the values present in the students pursuing the degree of teacher in primary education in the public universities of Andalucia”, which reveals the essential aspects of social and aesthetic 
concepts of values in youth; educational needs for learning values in university training (González-Gijón, 2020). The results of the theoretical analysis have shown that despite numerous studies of various aspects of the theory and practice of values in pedagogical specialists training, the scientific problem of the sociocultural dominants of developing future teachers' values in the context of civilizational challenges is not fully and systematically studied.

\section{Methodology}

To ensure the completeness of research, we have chosen axiological, sociocultural, interdisciplinary, and systems-activity approaches. In the process of scientific research, we gave preference to the systems-activity approach, as the value intentions development is considered in the process of teaching students of artistic and pedagogical specialties, which envisages their personal value motivation, choice of dominant sociocultural values and valuepersonal activity. The scientific field of research constitutes a holistic dimension of value interests and motives, a cognitive level and ways of activity, the relationship between the acceptance of sociocultural dominants and changes in value intentions that affect the value development and self-development of the individual. This interpretation is based on the scientific ideas of L. Vygotsky (Vygotsky, 2000).

An interdisciplinary approach allows combining interdisciplinary components of art, literature, history, ethics, pedagogy in line with the humancreating philosophy of education (Gershunsky, 1998).

To implement a comprehensive study of the above scientific problem a set of methods was used, namely: theoretical (analysis, generalization, comparison, systematization) - to determine the degree of elaboration of the problem in scientific sources; empirical - testing, interviewing - to ascertain the formation of the studied phenomenon; pedagogical experiment; methods of mathematical statistics (quantitative and qualitative processing of research results and statistical verification of their objectivity by Pearson's correlation using MS EXCEL (the function "Corel"). The choice of adequate methods for the purpose of the study is based on the results of theoretical analysis of the studies that reflect similar scientific problems.

The study was carried out in several stages. The purpose of the first stage of the study was to clarify the state of the problem, to identify in students-future teachers of the education and art field the value intentions based on sociocultural dominants.

To achieve the above goal, we used a group of empirical tools using the Google service and conducted: online surveys, interviews; analysis of products of students' educational activity (pedagogical essay); real-time pedagogical observation. The different stages of the study involved 356 respondents, the age range was 1835 years. We did not divide respondents by gender and nationality.

Procedure: in the developed case study, the respondents were selected in accordance with educational-professional training programs, namely: "Primary education", "Instrumental performance" (orchestral string, folk, wind and percussion instruments).

\section{Research results}

According to the results of the study, the profile of students of pedagogical specialties, the relationship between the attitude to sociocultural dominants and intrinsic motivation for the development of value intentions and valuepersonal self-development are analyzed. Therefore, we consider it expedient to single out the value-personal component of the content of future teachers training, which is based on the inner senses of the individual to conscious perception of himself in the profession, attitude to himself and others and is dominant in becoming a specialist. Note that pedagogical activity is multidimensional, it is expressed by psychophysiological, didactic, aesthetic, ethical determinants.

It is proved that in the sphere of human-human activity, which includes pedagogical and artistic education, value intentions are characterized by personal and professional components, and hence personal-value and professional content.

The results of the analysis of the content of educational programs in pedagogy, psychology, educational (psychological-pedagogical practices), professional methodologies allowed to establish the main interconnected tendencies: innovative and traditional (adaptation of separate practices of the past years to solving current tasks of specialists' value intentions development in conditions of the transformation of the educational paradigms).

A set of methods was used to identify current values in future specialists in pedagogical and art 


\section{$\frac{\text { AMAZONIA }}{\text { Drvestiga }}$}

education: surveys, interviews, pedagogical essays, mathematical statistics. Identification and generalization of the results of scientific research allowed to establish the following: $100 \%$ of respondents (full-time and part-time students of the 1, 2 years study) considered important for themselves in the professional plane the values of goodness and justice; in the ranking of dominant values it was found out that $77.3 \%$ preferred sociocultural and spiritual values; in second place there were family values (family, family care) - chosen by $54.5 \%$ of respondents; $50 \%$ of respondents preferred democratic values (freedom, justice, equality; respect for the individual); material values were paramount for $27.3 \%$ of respondents. A comparative analysis of the responses of students with teaching experience and those without such an experience shows the following: teachers with five years of teaching experience or more pay more attention to their own professional development and connect it with digital and other innovative technologies, the axiological component of professional activity mostly remains in the last place. In contrast to this group of respondents, full-time students (without pedagogical experience) in the ranking process distinguish sociocultural values in the first group and characterize them as being fundamental to human communities.
Interpretation of the obtained results is based on innovation and traditionalism (as discussed above). Excessive focus on the performance of narrow-profile tasks in teacher training is characterized by the longevity of the usual knowledge-normative educational paradigm of previous periods. Hence, there is an obvious substitution of the visions for training, which contradict the current tasks of preparing the young generation for life in a multicultural environment and forming their readiness to learn throughout life. In line with innovative trends in teacher training, the main thing is integration of knowledge about man and his values as a humancreating factor. Thus, anthropological correction of pedagogical reality is carried out in the conditions of change of pragmatic strategy to axiological.

To examine whether there is a relationship between students' positive attitudes toward sociocultural values and motivation to learn them, Pearson's correlation coefficient was calculated. A significant positive correlation was found ( $\mathrm{p}<0.01, \mathrm{r}=0.4$ ). A positive correlation was also found in the sample of EPP "Primary Education" $(p<0.01, r=0.34)$ and in applicants for higher education of the first (bachelor's) level in instrumental performance $(\mathrm{p}<0.05, \mathrm{r}=0.44)$.

Table 1.

Pearson's correlation between the average ratio of sociocultural dominants and the average indicators of value intentions assimilation.

\begin{tabular}{lll}
\hline & N & Pearson's correlation \\
\hline Total sample & 256 & $0.4^{* *}$ \\
$\begin{array}{l}\text { Students of the EPP "Primary Education" } \\
\begin{array}{l}\text { Students of the EPP "Instrumental } \\
\text { performance" (orchestral string, folk, wind } \\
\text { and percussion instruments) }\end{array}\end{array}$ & 153 & $0.34^{* *}$ \\
\hline
\end{tabular}

$* \mathrm{p}<.05, * * \mathrm{p}<.01$

Source: own authorship (2021)

Based on the obtained results, Pearson's tests were performed for each selected position separately. There was a significant correlation between the attitude to sociocultural heritage and motivation to study literature (oral folk art), history of culture and arts, contemporary art, native and state languages, written memorabilia for each of the subjects separately. The highest ratio for the arts was found, while the study of written memorabilia (written historical and literary sources) received the lowest correlation. 
Table 2.

Pearson's correlation between personal-value attitudes to education fields and the choice of value preferences

\begin{tabular}{ll}
\hline EDUCATION FIELDS & Pearson's correlation \\
\hline Languages and literatures & $0.43 * *$ \\
Oral folk art & $0.4 * *$ \\
History & $0.61 * *$ \\
History of arts, art & $0.41 * *$ \\
Ethics & $0.29 * *$ \\
\hline
\end{tabular}

$* \mathrm{p}<.05, * * \mathrm{p}<.01$

Source: own authorship (2021)

Regarding the question whether and to what extent there will be differences between those who have low and high academic achievements (grades) in motivation to study the sociocultural aspect of academic disciplines, we have identified three levels of students' achievements - low, medium, high. A one-way ANOVA was performed. No significant difference between the levels of academic achievements of students was found $-(F(3125)=0.79 ; p=$ n.s. $)$.

According to the results of the ascertaining stage of the study, the influence of sociocultural dominants on the development of value intentions of student youth is detected. Their content is increasingly filled with universal meaning and naturally affects the direction of students' interests and needs. At the same time, in our opinion, it is right to consider it to be one of the types of values, the semantic whole, which unites motives, needs, interests, attitudes, and ideals. It is here that the law operates: the broader aesthetic interests, the more defined the needs for artistic creativity or communication with art, the more formed taste and aesthetic position, the fuller in terms of values becomes an aesthetic attitude, the more spiritually significant.

Based on these provisions, we have identified several types of value intentions that reflect the value attitude of student youth to different arts and future teaching.

In order to determine the trends in the development of values of student youth in modern sociocultural realities in Ukraine, we studied the influence of the sociocultural dominants on the development of these personal qualities in students of art and pedagogical specialties of several universities in Ukraine and traditions of its development, as well as the needs of society and the possibility of meeting them in the sociocultural environment. The study involved 450 first- and second-year students.
Methods of observation, questionnaires, interviews, ranking, testing, rating were used.

Students were asked to fill out the questionnaires consisting of the open-ended questions to explore their ideas about aesthetic qualities, ethics, culture of behavior, the pursuit of the ideal. Note that the answers to the questions were varied and almost not repeated. When asked why modern man should strive for the ideal, students answered that it was an opportunity to be something better than others; gaining experience and self-improvement; development. Future professionals would like to be role models for those who: want to be familiar with different genres of music; loves art; does not know what he wants from life. According to students, a cultured person should observe etiquette rules and speak languages, respect others and take control of himself, strive to acquire knowledge. Respondents noted that a person had to do his job honestly, be purposeful, aware of the purpose of his activities.

Describing their aspirations in life, future professionals point out what they like; selfrealization and self-development; the desire for something new, for happiness and money, for the ideal. Aesthetic qualities are understood by students as the desire for beauty; love of classics in various arts; the ability to see beauty in everything around; obligatory features of the modern personality. Applicants form themselves as musicians; independent and decent personalities; qualities of a leader: resistance to life misfortunes, politeness, self-control.

Students believe that a person who has achieved respect, understands others, the world, everything, authority, has formed communicative qualities. They are grateful for the achievement of certain results to teachers of music schools and parents; other factors that 


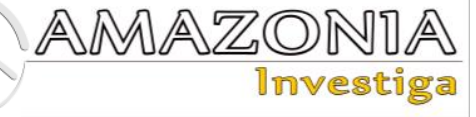

contributed to it are: fruitful work; efforts to overcome laziness; the environment; motivation. For students, the priority values in society are kindness, optimism; family; respect; money; moral values. In other people, students are attracted to such aspects as: the style of music that the person listens to; intelligence; independence, respect for others; responsibility for their words and deeds, sense of humor; ability to speak on "high topics". Students reflect on cultural issues when they are addressed; when observing the rudeness and disrespect of people for others; when communicating with people who cannot express their opinion.

Students' ideas about ethics are manifested in knowledge of etiquette and good manners; restraint; respect for each other; colors; people's actions. In aesthetic culture, students are attracted by the beauty that everyone aspires to; thirst to see the new and unusual; colors and books; the height from which aesthetics "looks" at the world. Students believe that art for modern man is an opportunity to learn something new; new genres in music and new styles in dance, a combination of different arts; self-development and peace of mind; way to make the world a better place. According to the respondents, beauty will save the world under such conditions, if: it reaches the highest value; is able to solve problems; beauty, reason and moral values are combined; becomes a priority in society. When asked about their desires and dreams, the students answered that they would like to "play in a rock band"; "always be smiling"; "be more relaxed"; "sleep and see friends"; "be happy"; "succeed and self-realize".

Getting into an inadequate situation, students try to: correct it; think adequately; quickly navigate and find a way out. Describing the decisions they regret, the respondents named situations when the actions: a) were, in their opinion, wrong; b) had bad consequences; c) did not bring the desired results. Memorable for students are those events that were "fun"; "caused strong emotions"; "full of bright and joyful moments"; "all were important"; "remain in photos and videos"; "evoke memories".

Answering open-ended questions on the principle of "continue the sentence", students formulated the following statements: to the question "Modern man should strive for the ideal to..." $30.4 \%$ of them answered "improve yourself". $17.4 \%$ would like to be a role model for those who want to become better. $34.8 \%$ of future professionals believe that a cultured person should observe the rules of etiquette, have moral values, knowledge and skills. To the question "Mandatory for a person in the activity is...", $34.8 \%$ of respondents answered "diligence"; $26.1 \%$ of respondents in life want to start a family, work and get an education. Aesthetic qualities are understood by $17.4 \%$ of students as "something beautiful". According to them, among the qualities that should be formed in the personality, $39.1 \%$ noted respect for cultural heritage, pride in one's culture and respect for other cultures; $21.7 \%$ - willpower, determination, humanity. Students note that a person who has achieved respect, first takes control of himself $(30.4 \%)$. To the question "Why do students achieve certain results?" they single out the following factors: "diligence and perseverance" (43.5\%), "help and faith of parents" (26.1\%). Among the highest priority values in society, respondents note respect, kindness and honesty $(69.6 \%)$. Other students are attracted by the following traits and qualities: openness, appearance $(30.4 \%)$, humor and zest for life $(17.4 \%)$. Forming their ideas about ethics, students note that it is "norms of behavior, a set of moral rules" (34.8\%). Cognition (13.0 $\%)$ and worldview $(13.0 \%)$ for students is the embodiment of art. Faced with an inadequate situation, $34.8 \%$ of students try to be calm, and $26.1 \%$ try to find a way out. When asked about the decisions they regret, $13.0 \%$ of students answered, "actions that could harm others", and $21.7 \%$ - "those that will not help them themselves". The most memorable events for students are those that are accompanied by positive emotions $(26.1 \%)$. The results of the study are presented in table 3 . 
Table 3.

The results of a survey of future professionals.

\begin{tabular}{|c|c|c|}
\hline Sentences to be continued & Variants of students' answers & $\begin{array}{l}\text { Percentage of answers } \\
\text { from the total number } \\
\text { of respondents }\end{array}$ \\
\hline \multirow{3}{*}{$\begin{array}{l}\text { Modern man should strive } \\
\text { for the ideal to... }\end{array}$} & Improve oneself & $30.4 \%$ \\
\hline & $\begin{array}{l}\text { Be a role model for those who want to be } \\
\text { better }\end{array}$ & $17.4 \%$ \\
\hline & $\begin{array}{l}\text { A cultured person must observe the rules } \\
\text { of etiquette, have moral values and skills }\end{array}$ & $34.8 \%$ \\
\hline \multirow{3}{*}{$\begin{array}{l}\text { Mandatory for the person in } \\
\text { the activity is... } \\
\text { I understand aesthetic } \\
\text { qualities as... }\end{array}$} & Hard work & $34.8 \%$ \\
\hline & Creating a family, work and education & $26.1 \%$ \\
\hline & Something beautiful & $17.4 \%$ \\
\hline \multirow{2}{*}{$\begin{array}{l}\text { Personality qualities that } \\
\text { should be formed in a } \\
\text { student... }\end{array}$} & Discipline, confidence, professionalism & $39.1 \%$ \\
\hline & Willpower, purposefulness, humanity & $21.7 \%$ \\
\hline $\begin{array}{l}\text { A person who has achieved } \\
\text { respect first of all... }\end{array}$ & Takes control of himself & $30.4 \%$ \\
\hline $\begin{array}{l}\text { What helps students achieve } \\
\text { certain results? }\end{array}$ & $\begin{array}{l}\text { Hard work and perseverance } \\
\text { Help and faith of parents }\end{array}$ & $\begin{array}{l}43.5 \% \\
26.1 \%\end{array}$ \\
\hline $\begin{array}{l}\text { The highest priority values in } \\
\text { society... }\end{array}$ & Respect, kindness, honesty & $69.6 \%$ \\
\hline $\begin{array}{l}\text { Traits and qualities that } \\
\text { attract you in others... }\end{array}$ & $\begin{array}{l}\text { Openness, appearance } \\
\text { Humor and zest for life }\end{array}$ & $\begin{array}{l}30.4 \% \\
17.4 \%\end{array}$ \\
\hline Your ideas about ethics... & Norms of behavior, a set of moral rules & $34.8 \%$ \\
\hline Personification of art... & $\begin{array}{l}\text { Cognition } \\
\text { World perception }\end{array}$ & $\begin{array}{l}13.0 \% \\
13.0 \%\end{array}$ \\
\hline $\begin{array}{l}\text { Getting into an inadequate } \\
\text { situation... }\end{array}$ & $\begin{array}{l}\text { Try to be calm } \\
\text { Trying to find a way out }\end{array}$ & $\begin{array}{l}34.8 \% \\
26.1 \%\end{array}$ \\
\hline $\begin{array}{l}\text { What decisions do you } \\
\text { regret? }\end{array}$ & $\begin{array}{l}\text { About actions that could harm others } \\
\text { Those that will not help them themselves }\end{array}$ & $\begin{array}{l}13.0 \% \\
21.7 \%\end{array}$ \\
\hline Most memorable events... & $\begin{array}{l}\text { Those that are accompanied by positive } \\
\text { emotions }\end{array}$ & $26.1 \%$ \\
\hline
\end{tabular}

Source: own authorship (2021)

The instability of economic development, the clash of globalization and regionalization, the prevalence of declarative moral norms in society over the existing ones affect the formation of a system of students' value orientations, according to which the central link in the system of responsibility for performance is the individual.

Analysis of modern training strategies, as well as practices of the educational process in higher education institutions reveals several trends in the formation of the system of value intentions development in future professionals. These trends have a binary character: radicalism of innovations and conservatism of traditions, though with the changed content, sense, values and vectors of development; incomprehensibility in the use of world experience and orientation towards isolationism; expansion of the technocratic approach to the procedure of assessing the quality of education.
It is known that tradition is always the value basis of any social system. First of all, the cultural tradition in which the values of society take place is important for art education. New forms of digital revolution, challenges and risks of network socialization affect the whole content of spiritual education, not only its individual components, namely: educational systems, theoretical ideas about the spiritual space of educational reality and its component - "space of spiritual education" (I. Kevishas).

Thus, we are currently witnessing modernization of value orientation in the fields of art and education (pedagogy), which is explained by intercultural globalization, penetration of digital technologies into all spheres of life and intensive development of the world educational space. This trend is reflected in the increase of spiritual significance for students of classical and folk music, rock music and in the critical attitude to the pop hit, in the stable awareness of national 


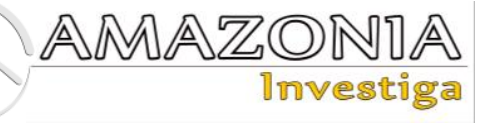

and cultural identity, reflected in the evaluation of works of art and so on. Meanwhile, there is a decline in the culture of reading literature about art and Ukrainian classics. We can say that the Internet factor determines special prospects in training modern specialists in the field of art, in particular, in reading literature about art.

Experimental data on aesthetic qualities, aesthetic communication, ethics, culture of behavior, striving for the ideal turned out to be quite interesting. The most valuable were the value intentions of students for the profession, although there are some contradictions between the focus on the end result as a form (completion of higher education, obtaining a profession) and content (mastery of professional competences).

Experimental research has shown that in the modern system of art and pedagogical education there is a need to organize large-scale interdisciplinary cooperation of teachers of music schools, colleges and institutions of higher art education for the development of student youth in continuing art education.

\section{Discussion}

Sociocultural reality is unique at a particular time and place, in relation to the general essence of human life and personal and professional meanings in the space of existence.

Theoretical analysis of research on the value dominants of human life, from abstract to concrete, throughout the history of culture leads to the conclusion that humanity seems to have woven the most important virtues, which are reflected in language, traditions, oral and written literature, philosophy, art, views on the upbringing of children and youth. The development of their value intentions is influenced by sociocultural dominants, which is constantly updated within human thought, with all its uniqueness and changing nuances.

Note that the interest in the sociocultural phenomenon today is due to the following circumstances: civilizational changes in the environment and social institutions; priority of the culture potential in the development of the individual and society. The difficulty of this reasoning lies in establishing links between the "personality-culture" dichotomy and overcoming the contradictions of the individual with various cultural and civilizational influences, including those generated by the dominance of technological consciousness.
In the scientific discourse of the twentieth century, there are diametrically opposed views of scientists in the fields of psychoanalysis ( $\mathrm{S}$. Freud, C. Jung, E. Neumann (Freud, 2013; Jung, Neumann, Freud, 1996)), philosophical anthropology (E. Fromm (Fromm, 2017)), sociobiology (M. Ruse, E. O. Wilson (Ruse, 1985; Wilson, 1979)) on the place and role of culture in the development of man and society.

The conceptual ideas of our study are based on understanding the priority of sociocultural influence on the formation of personal and professional values of future specialists in the field of education and art. Sociocultural dominants are considered as factors influencing the formation of the inner world of the individual and his value intentions, which are decisive for both the individual and social units and society as a whole. Culture in the personal sense is correlated with conscious work to improve one's own self-development and order all that surrounds a person. According to I. Kant's (2019) ideas, culture is a way of setting and achieving one's own goals, as well as the goals of moral improvement of society. The characteristic features of people's behavioral experience in the social environment of knowledge, which serve to meet individual intellectual and emotional needs in the process of self-development and professional development of the future teacher, have been experimentally confirmed. Therefore, we consider the relationship of cultural determinants with social transformations and their impact on the subjectpersonal aspect of man in the process of becoming a specialist in the field of pedagogical and art education.

It was found out The influence of sociocultural dominants on the development of value intentions of future specialists in pedagogical and art education in the context of civilizational challenges corresponds to the understanding of the essence of future specialist own involvement in social development as a carrier and product of the social environment values and transformation of previously acquired values under the influence of cultural (technological, social) processes. In general, culture characterizes a person as an active subject in the process of social development; concentrates his experience in the creation of natural and social environments, which is the basis for the continuity of the human mentality. A person develops as a personality in the process of assimilating a cultural space that contains a kind of social memory of generations. 
It was proved: sociocultural dominants are the architecture of humanizing education and teacher training. The content and methods used by the humanities are the only ones that support and contribute to the preservation and increase of culture and democracy in various spheres of human life. The humanities occupy a prominent place in teacher training. The content of the humanities serves as a tool for value intentions development in students of pedagogical specialties, which is the basis for the formation of critical thinking, creativity and empathy. In the course of the experiment it was established the predominance of pragmatic value intentions that we observe today in youth circles is a process and result of education, based on technological paradigms. The departure from humanistic values in education and daily life of human communities leads to the devaluation of sociocultural dominants and the severance of ingrained cultural ties. Therefore, it may affect the young person's perception of antisocial and anti-democratic values, formation of apathy to humanistic values. Since the personality is sociocultural in nature and individual and unique in the way of its existence, we consider its subjectivity in the course of the culturalhistorical process. To ensure the dynamism of the cultural process, man should be in constant development, based on socio-cultural dominants, and hence human civilization will be constantly developing.

The conducted experiment of this scientific problem in the context of preparation for professional activity of specialists in education and art gives grounds to say that the majority of students show a positive attitude to socio-cultural dominants that characterize universal meanings, namely: respect for man and his traditional culture, values of human health and life, traditional folk culture, etc. Agreeing that sociocultural dominants are the basic background of human culture, a significant number of respondents did not show readiness to study the culture of previous periods which indicates the contradictions of their perceptions. In this group of students mostly prefer modern pragmatic personal meanings - their own career, material security, leadership. We assume that the profile of graduates of pedagogical specialties of higher education institutions will be characterized by high cultural and professional status. To conduct the study, we have identified the following main issues that correspond to the profile of the higher education applicant of the (first) bachelor's degree level: what are the dominant values relevant to the teaching career (primary school teacher, head of a group playing musical instruments); personal and value portrait of a modern teacher; ranking by students of value dominants which most essentially correspond to a pedagogical profession in the conditions of social transformations; influence of value differences on the motivation to study the humanities, personal development and selfdevelopment.

\section{Conclusion}

The results of the study allow us to conclude that the humanities have not lost their human-creating potential in our time. It has been found that the young generation is motivated to develop their own moral sphere and they are value-centered. However, pragmatically oriented young people cannot always find in the content of the humanities, which include disciplines of art, pedagogy, those segments that are aimed at the future, the development of values of future professionals depends on the content of the educational process in their training. Common to specialists training in pedagogical and art education is their involvement in the stage of study at the university in the human-centered sociocultural content, which is a factor in the development of value intentions of the individual. Note that the sociocultural component and its value dominants are of interest to young people when they see its prospects and future orientation. We did not focus in the study on identifying the deep processes of humanities education and limited the range of research to those values that are clear and acceptable to young people.

\section{Bibliographic references}

Bekh, I.D. (2019). Component technology of ascent of a growing personality to spiritual values, The Horizon of Spirituality of Education, 39-55. URL: https://lib.iitta.gov.ua/719526/1/Gorizont2.p df

Elior, R. (2011). The struggle over the humanities, 25, 73-103. URL: https://www.wzo.org.il/Volume-25

Fromm, E. (2017) The Art of Loving. K.: KSD. URL:

https://bookclub.ua/catalog/books/psycholog y/mistectvo-lyubovi

Freud, Z. (2013) The discomfort in the culture. M.: Folio URL: https://www.yakaboo.ua/ua/nedovol-stvokulturoj.html?gclid=CjwKCAjwj8eJBhA5Eiw Ag3z0m7TIEUum4p_O6AdBKb56S1wEltQ 


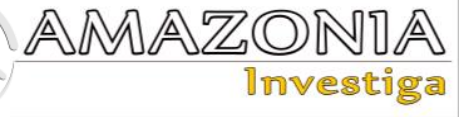

KF6I5wfsjrXa6YMefl8d5FnjUDhoC7BoQA vD_BwE\#media_popup_fragment

Gershunsky, B.S. (1998). Philosophy of Education for the 21st Century. (In search of practice-oriented educational concepts). M.: Publishing house «Sovershenstvo».

Goldman, S. (2014). Harvard and the humanities. First Things, 239, 20-21. URL: https://www.firstthings.com/article/2014/01/ harvard-and-the-humanities

González-Gijón, G., Martínez-Heredia, N., Amaro-Agudo, A., \& Soriano-Díaz, A. (2020). Study of the values present in the students pursuing the degree of teacher in primary education in the public universities of Andalucia. Formacion Universitaria, 13, 2 , 1 February, 83-92. DOI: 10.4067/S071850062020000200083

Jung, K.G., Neumann, E., \& Froud, Z. (1996) Psychoanalysis and art. M.: Folio. URL: https://www.yakaboo.ua/ua/psihoanaliz-iiskusstvo-1561305.html

Kant, I. (2019). Critique of Judgment. M.: Azbuka URL: https://www.yakaboo.ua/ua/kritikasposobnosti-suzhdenija2099818.html?gclid=CjwKCAjwj8eJBhA5E iwAg3z0m5s2GI8orWd42Bkx1Lyxgzct6HmpNrOTwfB_qvGqmLejxP3kUdxI BoCYaIQAvD_BwE\#tab-attributes

Kevishas, Y. \& Otych, O. (2019). The Horizon of Spirituality of Education. Vilnius: Žuvédra. URL https://lib.iitta.gov.ua/719526/1/Gorizont2.p df

Lyberger, M.R. (2020). Value-centric education: A transcending approach. Sport Management Education Journal, 14, 1, 52-54. URL: https://journals.humankinetics.com/view/jou rnals/smej/14/1/article-p52.xml

Oleksiuk, O.M. (2019). Development of the spiritual potential of the individual in postclassical art education. Kyiv: KUBG. URL: https://elibrary.kubg.edu.ua/id/eprint/29712/

Orekhova, Y.Y., Grebenkina, L.K., Zhokina, N.A., Kushnyr, L.A., \& Samotaev, P.I. (2020). Formation of students' values-based attitude to the future teaching profession as moral basis of pedagogical ethics. Periodico Tche Quimica, 17(34), 260-272.

URL: https://journals.indexcopernicus.com/api/file /viewByFileId/1018981.pdf

Panev, V. (2020). Theoretical basis and models for developing students' values in primary education. International Journal of Cognitive Research in Science, Engineering and Education, 8, 1, 81-91. DOI https://doi.org/10.5937/IJCRSEE2001081P

Rinon, Y. (2014). The Crisis in the Humanities. Tel Aviv: Hakibbutz Hameuchad. URL: https://www.cambridgescholars.com/product 1978-1-4438-9782-2

Ruse, M. (1985) Sociobiology: Sense or Nonsense? Netherlands: Springer. DOI: 10.1007/978-94-009-6438-9

Starecek, A., Koltnerova, K., Gyurak Babelova, Z., Caganova, D., Lovasikova, S., \& Ivic, M. (2019). Value orientations of generation $\mathrm{Z}$ and their performance in education process. ICETA 2019, 17th IEEE International Conference on Emerging eLearning Technologies and Applications, 9040060, 739-744. DOI: 10.1109/ICETA48886.2019.9040060

Uchyła-Zroski, J. (2016). The values of music education of children and youth in the perspective of tradition and modernity. University of Silesia, 168(2). URL: https://integro.ciniba.edu.pl/integro/1927054 86331/uchyla-zroski-jadwiga/wartosciedukacji-muzycznej-dzieci-i-mlodziezy-wperspektywie-tradycji-iwspolczesnosci?_lang=en

Vygotsky, L.S. (2000). Psychology. M.: EKSMO-Press.

URL: http://lib.mgppu.ru/opacunicode/app/webroo t/index.php?url=/notices/index/IdNotice: 124 40/Source:default

Wilson, E.O. (1979) On Human Nature. Harvard University Press. URL: https://www.hup.harvard.edu/catalog.php?is bn $=9780674016385$

Zhussupova, Z., Seitenova, S., Yeleussinova, G., Baimakhanova, G., Bekeshova, G., \& Baimakhan, S. (2020). Value regulation of leadership behavior of education managers. Talent Development and Excellence, 12, 1, 269-278.

URL: https://www.iratde.com/index.php/jtde/articl e/view/604 